\title{
Cannabis legalization: adhering to public health best practice
}

\author{
Sheryl Spithoff MD, Brian Emerson MD MHSc, Andrea Spithoff MA
}

CMAJ Podcasts: author interview at https://soundcloud.com/cmajpodcasts/150657-ana

A ccording to the 2011 United Nations World Drug Report, the prevalence of cannabis use in the Netherlands, where cannabis has been de facto legal for the last 40 years, is lower than in many other European countries, the United States and Canada. ${ }^{1}$ Jurisdictions that have recently legalized cannabis (Uruguay and four US states) or redefined cannabis legalization policies (Catalonia) may be expecting a similar result. However, if their policies governing cannabis are different, they may see different outcomes.

In this article, we analyze cannabis legalization policies through a public health lens using a framework ${ }^{2}$ created from extensive data on tobacco $^{3}$ and alcohol regulation. ${ }^{4}$ The aim of this article, and indeed the framework, is to go beyond reduction in use and include minimization of harms and realization of benefits. ${ }^{5}$ Cannabis policy will be a topic of debate in Canada in the lead-up to the federal election in October. The governing party favours the status quo, one of the competing political parties has promised decriminalization, and another party supports legalization. ${ }^{6}$ Surveys have shown that most Canadians are looking for change. ${ }^{7,8} \mathrm{We}$ provide a resource for Canadian policy-makers looking to reform cannabis laws and a tool for researchers evaluating cannabis policies and their outcomes.

\section{A broad picture of cannabis use and legality}

A 2013 UNICEF study found that the prevalence of cannabis use among youth in the preceding year was highest in Canada (28\%) and lower in Spain (24\%), the US (22\%) and the Netherlands $(17 \%) .{ }^{9}$ A 2014 survey in Uruguay found that $17 \%$ of secondary school children reported using cannabis in the preceding year. ${ }^{10}$ According to the 2011 UN World Drug Report, cannabis use in the general population was higher in Canada, the US and Spain than in Uruguay and the Netherlands. ${ }^{1}$ There are an estimated 180.6 million cannabis users worldwide, ${ }^{11}$ most living in jurisdictions where cannabis is illegal.
In the past three years, Uruguay and four US states have gone beyond the limited legalization policies in Spain and the Netherlands to fully legalize the possession, production and sale of cannabis. Many other jurisdictions have removed criminal penalties for possession or have legalized cannabis for medical use, or both. Canada legalized the use of cannabis for medical indications in 2001 and implemented updated regulations for medical use and production in 2014..$^{12}$ Possession of cannabis for nonmedical use remains a criminal offence, and about 60000 Canadians are charged yearly. ${ }^{13}$

Legalization of cannabis for nonmedical use remains contrary to the 1961 UN Single Convention on Narcotic Drugs. Signatory countries can address this by renegotiating, withdrawing from or ignoring the treaty. Uruguay has chosen the third approach, arguing that its legalization framework follows the more important UN values of human rights, public health and safety. ${ }^{14}$

\section{What are the harms from cannabis use and its prohibition?}

Policies that prohibit cannabis cause harm. ${ }^{15}$ They funnel money into the illegal market and drive criminal activity. They harm individuals through imprisonment, marginalization and the creation of barriers to treatment. This burden falls disproportionately on vulnerable groups; even though white and black Americans use cannabis at about the
Competing interests: None declared.

This article has been peer reviewed.

Correspondence to: Sheryl Spithoff,

sheryl.spithoff@wchospital.ca

CMAJ 2015. DOI:10.1503 /cmaj.150657

\section{KEY POINTS}

- Prohibition of cannabis has failed to achieve its goal of reducing use and causes substantial public health and societal harm.

- Two of Canada's three main political parties promise to reform cannabis policies if voted into power.

- If Canadian policy-makers move away from prohibitionist policies and create a legal framework for cannabis, public health promotion and protection must be the primary goals.

- Lessons learned from permissive alcohol and tobacco regulation can guide public health-oriented policy-making; in particular, a ban on promotion and advertising of cannabis to prevent commercialization will be important.

- Policy-makers should look to jurisdictions with legalized cannabis that prioritize public health and use evidence, not ideology, to guide policies. 
same rate, the latter are 3.73 times more likely to be arrested for possession. ${ }^{16}$ Finally, society pays with high policing, court and prison costs. ${ }^{15,17}$

Harms from regular cannabis use may be less than those associated with other psychoactive substances ${ }^{18}$ but they are still substantial at a population level. At higher doses, cannabis is a wellestablished risk for motor vehicle crashes. ${ }^{19,20}$ Combining alcohol with cannabis results in greater impairment than either substance alone. ${ }^{21}$ A recent study estimated that 6825-20 475 injuries from cannabis-attributed motor vehicle crashes occur in Canada annually. ${ }^{19}$ Each year in Canada, 76 000-95 000 people undergo cannabis addiction treatment and 219-547 cannabis-related deaths occur (from injuries in motor vehicle crashes and lung disease). ${ }^{19}$ Youth are particularly vulnerable to the effects of cannabis: regular users frequently report loss of control over their cannabis use, ${ }^{22}$ have lower educational attainment ${ }^{23}$ and may have, according to one cohort study, a drop in IQ that persists into adulthood. ${ }^{24}$

Often the harms from prohibition versus harms from potential increased use of cannabis are falsely pitted against each other. Evidence shows, however, that cannabis prohibition has no effect on rates of use, at least in developed countries. ${ }^{25-28}$

Some have advocated for the removal of criminal penalties for possession instead of legalization. With Portugal's experience in decriminalizing cannabis, users benefit from reduced marginalization, imprisonment and barriers to treatment, and society benefits from reduced policing, court and prison costs. ${ }^{17}$ The illegal supply chain, however, continues to fund criminal activity. In addition, because the government does not control the production, processing, supply or price of cannabis, it has a limited ability to achieve public health goals.

\section{What objectives should underpin legalization?}

If policy-makers opt to legalize cannabis, careful planning and comprehensive governmental controls would provide the greatest likelihood of minimizing harms and maximizing benefits. A cannabis legalization framework should explicitly state that public health promotion and protection are its primary goals. It should list specific objectives, ${ }^{5,29,30}$ including delayed onset of use by youth; reduced demand; reduced risky use (e.g., reduced impaired driving); decreased rates of problematic use, addiction and concurrent risky use of other substances; reduced consumption of products with contaminants and uncertain potency; increased public safety (e.g., reduced drug-related crime); reduced discrimina- tion, stigmatization and marginalization of users; and realization of therapeutic benefits.

A frequently cited concern with legalization is that it will allow the rise of Big Cannabis, ${ }^{31}$ similar to Big Tobacco and Big Alcohol. These powerful multinational corporations have revenues and market expansion as their primary goals, with little consideration of the impact on public health. They increase tobacco and alcohol use by lobbying for favourable regulations ${ }^{32}$ and funding huge marketing campaigns. ${ }^{33}$ It is important that the regulations actively work against the establishment of Big Cannabis.

\section{Evaluating cannabis regulations through a public health lens}

There is scant direct evidence to guide the creation of public health-oriented cannabis policies. Fortunately, there is an extensive evidence base for two other substances with potential for addiction and other harms: tobacco ${ }^{3}$ and alcohol. ${ }^{4}$ With these data, researchers have proposed policy frameworks for cannabis. ${ }^{28-30,34}$

For our analysis, we built on previous work, ${ }^{29,35-38}$ using a framework created by Canadian public health researchers ${ }^{2}$ that was based on a report by the Health Officers Council of British Columbia. ${ }^{5}$ We included jurisdictions with well-articulated cannabis policies and regulations, which we analyzed from a public health perspective using a systematic method (Table 1).

\section{Uruguay}

Uruguay follows the key public health best practices. ${ }^{40}$ It has established a central, governmental, arm's length commission to purchase cannabis from producers and sell to distributors. The commission will have control over production, quality and prices, and the ability to undercut the illegal market. ${ }^{41}$ Uruguay has banned cannabis-impaired driving and has set the cut-off for impaired driving to a serum tetrahydrocannabinol (THC) level of $10 \mathrm{ng} / \mathrm{mL}$. Because of its zero-tolerance policy for alcohol-impaired driving, the country has created a lower threshold for the combination of cannabis and alcohol. Tax revenues will fund the commission and a public health campaign. (Cannabis will initially be sold tax free to undercut the illegal market.) Uruguay bans all promotion of cannabis products. Pharmacies will sell bulk cannabis in plain bags, labelled only with the THC percentage and warnings. (Sales are slated to start early in 2016.) Individuals are permitted to grow their own cannabis and to form growing cooperatives. People who purchase or grow cannabis will be registered and fingerprinted to prevent 
Table 1: Policy strategies for the legalization of cannabis, and level of adherence by jurisdiction, based on an analysis of public health best evidence from the regulation of tobacco and alcohol ${ }^{2,3}$

\begin{tabular}{|c|c|c|c|c|c|c|}
\hline \multirow[b]{2}{*}{ Strategy } & \multicolumn{6}{|c|}{ Portion of core policies adhered to by jurisdiction } \\
\hline & $\begin{array}{l}\text { The } \\
\text { Netherlands }\end{array}$ & $\begin{array}{l}\text { Oregon } \\
\text { State }\end{array}$ & $\begin{array}{l}\text { Washington } \\
\text { State }\end{array}$ & $\begin{array}{l}\text { Colorado } \\
\text { State }\end{array}$ & Uruguay & Catalonia \\
\hline \multicolumn{7}{|l|}{ Availability and accessibility } \\
\hline $\begin{array}{l}\text { Control structure: The government should form a central commission } \\
\text { with a monopoly over sales and control over production, packaging, } \\
\text { distribution, retailing, promotion and revenue allocation. The primary } \\
\text { goal should be public health promotion and protection (to reduce } \\
\text { demand, minimize harms and maximize benefits). The commission should } \\
\text { be at arm's length from the government to resist interference with this } \\
\text { goal, such as industry influence and the government's desire to increase } \\
\text { revenues from promoting sales, fees and taxation. }\end{array}$ & $\begin{array}{l}\text { Few or } \\
\text { none }\end{array}$ & $\begin{array}{l}\text { Few or } \\
\text { none }\end{array}$ & $\begin{array}{l}\text { Few or } \\
\text { none }\end{array}$ & $\begin{array}{l}\text { Few or } \\
\text { none }\end{array}$ & Most & NA \\
\hline $\begin{array}{l}\text { Provision to consumers: Cannabis should be sold only at licensed or } \\
\text { commission-operated retail outlets. Public health objectives should determine } \\
\text { the locations and the appearance of the outlets. Health promotion messages } \\
\text { should be displayed. Hours of operation should be limited. }\end{array}$ & $\begin{array}{l}\text { Few or } \\
\text { none }\end{array}$ & Some & Some & Some & Most & NA \\
\hline $\begin{array}{l}\text { Price: The price should be set high enough to reduce demand, and low } \\
\text { enough to undercut the illegal market. }\end{array}$ & $\begin{array}{l}\text { Few or } \\
\text { none }\end{array}$ & $\begin{array}{l}\text { Few or } \\
\text { none }\end{array}$ & Some & $\begin{array}{l}\text { Few or } \\
\text { none }\end{array}$ & Most & NA \\
\hline $\begin{array}{l}\text { Locations for use: The public should not be exposed to cannabis smoke. Use } \\
\text { should be restricted to licensed locations (or private homes). Cannabis lounges } \\
\text { should be neutral, not promote cannabis use and include health promotion } \\
\text { material. Alcohol and tobacco use should not be permitted. Locations, hours } \\
\text { and amounts of a sale to an individual should be restricted. }\end{array}$ & Some & ND & NA & NA & NA & Most \\
\hline $\begin{array}{l}\text { Cannabis and driving: } \text { Cannabis-impaired driving should be an offence } \\
\text { with a range of available legal sanctions. There should be active and visible } \\
\text { enforcement along with prevention campaigns. Testing should be effect } \\
\text { based (i.e., road-side impairment testing) confirmed with blood testing. } \\
\text { Zero tolerance is not recommended because THC detection may occur long } \\
\text { after effects have resolved. There should be lower thresholds for the } \\
\text { combination of cannabis and alcohol because the effects are additive. }\end{array}$ & Some & Some & Some & Some & Most & Some \\
\hline \multicolumn{7}{|l|}{ Supply } \\
\hline \multicolumn{7}{|l|}{ Demand drivers/mitigators } \\
\hline $\begin{array}{l}\text { Promotion and packaging: All branding and promotion (e.g., advertising, } \\
\text { sponsorship and product placement } \S \text { ) should be banned. Partial bans } \\
\text { have little effect. Labels should include information on health risks. }\end{array}$ & Most & ND & $\begin{array}{l}\text { Few or } \\
\text { none }\end{array}$ & $\begin{array}{l}\text { Few or } \\
\text { none }\end{array}$ & Most & Most \\
\hline $\begin{array}{l}\text { School and public education campaigns: : The government should } \\
\text { support evidence-based school and public education campaigns to temper } \\
\text { demand. Large, mass-media campaigns should be avoided because they } \\
\text { can stimulate interest and increase use. }\end{array}$ & NE & NE & NE & $\mathrm{NE}$ & NE & NE \\
\hline \multicolumn{7}{|l|}{ Dedicated revenue } \\
\hline $\begin{array}{l}\text { Dedicated revenue: The revenue should be used for health and social } \\
\text { initiatives. }\end{array}$ & $\begin{array}{l}\text { Few or } \\
\text { none }\end{array}$ & Most & Most & Most & Most & NA \\
\hline
\end{tabular}

Note: ND = not yet defined, NA = not applicable, NE = not evaluated, THC = tetrahydrocannabinol.

*Items in italics have moderate to strong evidence from the tobacco, alcohol and cannabis literature to support them. Other items have weaker evidence to support them or are the authors' recommendations ${ }^{2}$ based on the cannabis literature and public health goals.

tBecause cannabis-impaired driving was not addressed in the framework article, ${ }^{2}$ we relied on other similar sources to create this section. ${ }^{19,20,28-30,34,39}$ This area is rapidly evolving, with a currently unclear association between cannabis levels in bodily fluids and effects on driving. Policies should change as the evidence changes. Evidence currently supports a blood THC level of 3.5-5 ng/mL (serum level 7-10 ng/mL) as a reasonable threshold for impaired driving. Per se laws (automatic ticketing above a threshold concentration in blood even without demonstrated impairment) are gaining popular support. These laws concern some experts because they may lead to charges for individuals who are not impaired.

fEvidence-based school and public education campaigns can be effective measures in reducing demand and harm. However, we excluded them from our analysis because of the complexity and difficulty of ascertaining what is happening in each jurisdiction.

§See examples in Appendix 1 (available at www.cmaj.ca/lookup/suppl/doi:10.1503/cmaj.150657/-/DC1). 
consumers from buying more than $480 \mathrm{~g}$ per year. This approach, however, gives rise to concerns around privacy and may encourage some to purchase cannabis from the illegal market.

\section{The Netherlands}

The Netherlands has a complex system governed by accepted practice rather than explicit policy. It decriminalized cannabis almost 40 years ago. Around the same time, it started to tolerate the buying and selling of small amounts in strictly controlled locations (the production and importing of cannabis remains illegal). ${ }^{42} \mathrm{As}$ long as these coffee shops sold small amounts, did not advertise or market, did not sell to minors and were "good neighbours," they were permitted to sell cannabis. ${ }^{43}$ This is still the practice 40 years later, and the Netherlands continues to struggle with the "back door" problem of an illegal supply chain. ${ }^{44}$ The government does not control production, packaging or price, nor is it able to legally tax cannabis products. The illegal supply chain continues to fund the illegal market. The government does, however, ban all promotion. This ban may be an important contributor to the low rates of use among youth in the Netherlands.

\section{Spain}

Spain has taken a different approach: it permits people to grow their own cannabis but prohibits private for-profit cannabis enterprises ${ }^{45}$ The country's Supreme Court ruling in the 1970s opened the door for nonprofit cannabis co-operatives, or cannabis social clubs. The first such club opened in Barcelona in 2001, and until recently, the clubs were guided by voluntary adherence to a code of practice. Many clubs, however, had lax enforcement of the membership rules. As a result, the government in Catalonia (an autonomous region in Spain where most of the cannabis social clubs are located) recently passed recommendations to guide municipalities in licensing the clubs. ${ }^{46,47}$ These recommendations include limits on monthly personal amounts of cannabis, hours of operation and membership. They also ban all promotion.

Catalonia's approach uses elements of a public health framework and eliminates the risk of harms associated with the involvement of profit-driven corporations. However, because production and use occur in private locations, the government has limited ability to ensure safety and quality, and to ensure that the focus remains on public health promotion inside the club doors. In addition, because the model restricts access to people who grow cannabis for personal use or are invited into a cannabis social club, some people may be excluded from obtaining cannabis legally.

\section{Oregon, Washington State, Colorado}

The US states of Oregon, Washington and Colorado all have an arm's-length commission to create and police cannabis policies, and to license producers and sellers. ${ }^{48-51}$ The commissions control the sellers' locations and hours and amount of sales, and they prohibit sales to people less than 21 years old. The states ban cannabis-impaired driving. Washington and Colorado have per se laws, with automatic ticketing for a blood THC concentration above $5 \mathrm{ng} / \mathrm{mL}$. Colorado allows drivers to rebut the charges if they can show they were not impaired. All three states control the product constituents and set labelling requirements. They permit the sale of pre-made cigarette-type cannabis products, not just bulk products. Most revenues are earmarked for health and social programs.

The commissions do not have a monopoly on supply. (This monopoly model has precedent in the US: many states have a central governmental monopoly for liquor). Instead, the states permit direct sales from producers to retailers. Colorado and Oregon go one step further and permit producers to be retailers. The commissions therefore have little control over supply and prices. In addition, they do not control cannabis taxation and must appeal to the state legislature for changes. Accordingly, Colorado and Washington State initially struggled with a price of legal cannabis that was much higher than the price of illegal cannabis. If the price of legal cannabis falls because of more efficient production, the opposite problem may occur: cheap legal cannabis, a known demand driver. ${ }^{52}$ Washington State has taken steps to counteract the lack of control and the risk of oversupply by limiting the number of producers and total production capacity. ${ }^{53}$

The states have set few controls over other demand drivers. Washington and Colorado permit all forms of promotion (advertising, branding and sponsorship) with few limits except on promotion to youth. Colorado asks industry "to refrain from advertising where more than approximately 30 percent of the audience is reasonably expected to be under the age of 21." ${ }^{\prime 50}$ Washington's regulations state that youth under age 21 should not be exposed to mass-media advertising, but they do not explain how this is to be done..$^{54}$ The states are hampered in creating stricter regulations by constitutional protection of commercial free speech. ${ }^{55,56}$

Because the states have limited control over supply and price, and permit promotion, there is little to stop the rise of Big Cannabis and its associated lobbying and marketing power. Washington State may be somewhat protected with limits it has placed on producer size and production. The states are at risk of an increase in cannabis use over time. On the positive side, these states should 
see a reduction in crime, harms to cannabis users (from incarceration and marginalization), and policing, court and prison costs. ${ }^{17}$

\section{How should Canada proceed?}

Canada has started down the path to a regulated market by implementing commercial production of cannabis for therapeutic purposes. Concurrently, there is a proliferation of unregulated cannabis dispensaries, especially in Vancouver and Victoria. Both municipalities are moving to regulate these operations. ${ }^{57,58}$

Given the evolving political and social landscape, and the upcoming federal election, Canada may soon revisit its policy on nonmedical cannabis. The federal government could create regulations or delegate this responsibility to provincial governments, either through an exemption to the Controlled Drugs and Substances Act (as was done in British Columbia to permit a supervised injection site) or through statute amendment (as happened with gambling ${ }^{59,60}$ ).

If Canadian policy-makers decide to create a legal, regulatory framework for cannabis, it is critical that public health objectives be the foundation of changes. Otherwise, Canada may experience the same health and social harms that resulted from the commercialization of alcohol and tobacco. The Canadian public would likely support a model that has public health as its primary goal..$^{61,62}$

Policy-makers can use tobacco and alcohol research and the frameworks for cannabis policy created by public health researchers as a guide. They can also learn from the experiences of other jurisdictions. Spain and Uruguay have models that could be adapted for use in Canada (without the registration and fingerprinting of consumers that Uruguay requires). The American models do not put public health first and risk the rise of Big Cannabis and increased harms, and the Dutch model has not solved the "back door" illegal supply problem. With careful planning, Canada can create its own policy framework for legalized cannabis that achieves public health objectives.

\section{References}

1. World drug report 2011. Vienna: United Nations Office on Drugs and Crime; 2011:209-40. Available: www.unodc.org/documents/ data-and-analysis/WDR2011/StatAnnex-consumption.pdf (accessed 2015 Sept. 2).

2. Haden M, Emerson BP. A vision of cannabis regulation: a public health approach based on lessons learned from the regulation of alcohol and tobacco. Open Medicine 2014;8:e73-80.

3. WHO framework convention on tobacco control. Geneva: World Health Organization; 2003. Available: www.who.int/fctc/ text_download/en/ (accessed 2015 Apr. 30).

4. Babor TF, Caetano R, Casswell S, et al. Alcohol: no ordinary commodity: research and public policy. Oxford (UK): Oxford University Press; 2010. Available: www.oxfordscholarship. com/view/10.1093/acprof:oso/9780199551149.001.0001/acprof -9780199551149 (accessed 2015 Apr. 30).

5. Public health perspectives for regulating psychoactive sub- stances: What we can do about alcohol, tobacco, and other drugs? Health Officers Council of British Columbia; 2011. Available: https://healthofficerscouncil.files.wordpress.com /2012/12/regulated-models-v8-final.pdf (accessed 2015 Apr. 30).

6. Health and safety, justice and law: where Canadian political parties stand on marijuana [blog]. The Fifth Estate 2015 Jan. 29. Available: www.cbc.ca/fifth/blog/where-canadian-political -parties-stand-on-marijuana (accessed 2015 Aug. 5).

7. Six-in-ten Canadians support legalizing marijuana, but say it's not a top justice priority [Canada public opinion poll]. Angus Reid Global 2014 Aug. 12. Available: http://angusreidglobal.com/wp -content/uploads/2014/08/ARG-Marijuana-Opinions2.pdf (accessed 2015 Aug. 20).

8. Kennedy M. Government's poll shows Canadians want marijuana laws changed. Ottawa Citizen 2014 July 30. Available: http://ottawa citizen.com/news/politics/conservative-governments-poll-shows -canadians-want-marijuana-laws-changed (accessed 2015 Aug. 19).

9. Office of Research Innocenti report card 11: Child well-being in rich countries: a comparative overview. Florence: UNICEF; 2013. Available: www.unicef.ca/sites/default/files/imce uploads/DISCOVER/OUR\%20WORK/ADVOCACY/DOMESTIC /POLICY\%20ADVOCACY/DOCS/unicef_report_card_11.pdf (accessed 2015 June 12).

10. Boidi F, Maria JMC, Queirolo R, et al. Marijuana legalization in Uruguay and beyond: executive summary. Insights Research Group; Latin America and Caribbean Center, FIU; Universidad Católica del Uruguay; 2015. Available: www.wilsoncenter.org/ sites/default/files/Marijuana\%20Legalization\%20in\%20Uruguay $\% 20$ and \%20Beyond_brief\%20report_v3\%20\%282\%29.pdf (accessed 2015 Aug. 17)

11. World Drug Report 2013. Vienna: United Nations Office on Drugs and Crime; 2013. Available: https://www.unodc.org/ unodc/secured/wdr/wdr2013/World_Drug_Report_2013.pdf (accessed 2015 Sept. 2)

12. Marihuana for Medical Purposes Regulations. SOR/2013-119. Available: http://laws-lois.justice.gc.ca/eng/regulations/SOR -2013-119/index.html (accessed 2015 Sept. 6)

13. Police-reported crime for selected offences, Canada [Table 1]. Ottawa: Statistics Canada; 2014. Available: www.statcan.gc.ca/ daily-quotidien/140723/t140723b001-eng.htm (accessed 2015 July 10).

14. Hetzer H, Walsh J. Pioneering cannabis regulation in Uruguay. New York: North American Congress on Latin America (NACLA); 2014. Available: https://nacla.org/article/pioneering -cannabis-regulation-uruguay (accessed 2015 Aug. 18).

15. War on drugs: report of the Global Commission on Drug Policy June 2011. Rio de Janeiro: Global Commission on Drug Policy; 2011. Available: www.globalcommissionondrugs.org/wp-content/ themes/gcdp_v1/pdf/Global_Commission_Report_English.pdf (accessed 2015 Aug. 15)

16. The war on marijuana in black and white: billions of dollars wasted on radically biased arrests. New York: American Civil Liberties Union; 2013. Available: www.aclu.org/files/assets/ aclu-thewaronmarijuana-rel2.pdf (accessed 2015 June 23).

17. Hughes CE, Stevens A. What can we learn from the Portuguese decriminalization of illicit drugs? Br J Criminol 2010;50:999-1022

18. Nutt DJ, King LA, Philips LD. Drug harms in the UK: a multicriteria decision analysis. Lancet 2010;376:1558-65.

19. Fischer B, Imtiaz S, Rudzinski K, et al. Crude estimates of cannabis-attributable mortality and morbidity in Canada - implications for public health focused intervention priorities. J Public Health (Oxf) 2015; Jan 28:pii: fdv005.

20. Drummer OH, Gerostamoulos J, Batziris H, et al. The involvement of drugs in drivers of motor vehicles killed in Australian road traffic crashes. Accid Anal Prev 2004;36:239-48.

21. Sewell R, Poling J, Sofuoglu M. The effect of cannabis compared with alcohol on driving. Am J Addiction 2009;18:185-93.

22. Nocon A, Wittchen HU, Pfister H, et al. Dependence symptoms in young cannabis users? A prospective epidemiological study. J Psychiatr Res 2006;40:394-403.

23. Hall W. What has research over the past two decades revealed about the adverse health effects of recreational cannabis use? Addiction 2015;110:19-35.

24. Meier MH, Caspi A, Ambler A, et al. Persistent cannabis users show neuropsychological decline from childhood to midlife. Proc Natl Acad Sci U S A 2012;40:E2657-2664.

25. MacCoun RJ, Reuter PH. Drug war heresies: learning from other vices, time \& places. Cambridge (UK): Cambridge University Press; 2001.

26. Simons-Morton B, Pickett W, Boyce W, et al. Cross-national comparison of adolescent drinking and cannabis use in the United States, Canada, and the Netherlands. Int J Drug Policy 2010;21:64-9.

27. Canadian Drug Policy Coalition. Getting to tomorrow: a report on Canadian drug policy. Vancouver: Simon Fraser University; 2013. 
28. Room R, Fischer B, Hall W, et al. Cannabis policy: moving beyond stalemate. Oxford (UK): Oxford University Press/Beckley Foundation Press; 2010.

29. Rolles S, Murkin G. How to regulate cannabis: a practical guide Bristol (UK): Transform Drug Policy Foundation; 2013. Available: www.unodc.org/documents/ungass2016/Contributions/Civil/ Transform-Drug-Policy-Foundation/How-to-Regulate-Cannabis -Guide.pdf (accessed 2015 Aug. 16)

30. Pacula RL, Kilmer B, Wagenaar AC, et al. Developing public health regulations for marijuana: lessons from alcohol and tobacco. Am J Public Health 2014;104:1021-8.

31. Carroll R. Big Cannabis: Will legal weed grow to be America's next corporate titan? The Guardian [UK] 2014 Jan. 3. Available: www.theguardian.com/politics/2014/jan/03/legal-marijuana -colorado-big-tobacco-lobbying (accessed 2015 Apr. 30).

32. Gornall J. Europe under the Influence. BMJ 2014;348:g1166.

33. Jernigan DH. The global alcohol industry: an overview. Addiction 2009;104(Suppl 1):6-12.

34. Cannabis policy framework. Toronto: Centre for Addiction and Mental Health; 2014. Available: www.camh.ca/en/hospital/about camh/influencing_public_policy/Documents/CAMHCannabis PolicyFramework.pdf (accessed 2015 June 12).

35. Room R. Legalizing a market for cannabis for pleasure: Colorado, Washington, Uruguay and beyond. Addiction 2014;109:345-51.

36. Pardo B. Cannabis policy reforms in the Americas: a comparative analysis of Colorado, Washington, and Uruguay. Int J Drug Policy 2014;25:727-35.

37. Kilmer B, Kruithof K, Pardal M, et al. Multinational overview of cannabis production regimes. Research and Documentation Centre (WODC), Dutch Ministry of Security and Justice; 2013. Available: www.rand.org/pubs/research_reports/RR510.html (accessed 2015 June 12).

38. Walsh J, Ramsey G. Uruguay's drug policy: major innovations, major challenges. Washington (DC): Brookings/WALA; 2015 Available: www.brookings.edu/ /media/Research/Files/Papers /2015/04/global-drug-policy/Walsh--Uruguay-final.pdf?la=en (accessed 2015 Aug. 14)

39. Grotenhermen F, Leson G, Berghaus G, et al. Developing limits for driving under cannabis. Addiction 2007;102:1910-7.

40. Marihuana y sus derivados: control y regulación del estado de la importación, producción, adquisición, almacenamiento, comercialización y distribución. Law no. 19.172. Senate and House of Representatives of the Oriental Republic of Uruguay, meeting in Assembly General. Available: www.correo.com.uy/otrosdocumentos/pdf/Ley 19.172.pdf (accessed 2015 June 2).

41. Castaldi M. Uruguay to sell marijuana tax-free to undercut drug traffickers. Reuters 2014 May 19. Available: www. reuters.com/article/2014/05/19/us-uruguay-marijuana -idUSKBNODZ17Z20140519 (accessed 2015 June 11).

42. Bieleman B, Nijkamp R, Reimer J, et al. Coffeeshops in Nederland 2012 [Dutch]. Groningen (the Netherlands): WODC, ministerie van Veiligheid en Justitie, Den Haag; 2013. Available: http://voc-nederland.org/persberichten_pdf/rapport-coffeeshops -in-nederland-2012-2.pdf (accessed 2015 Sept. 8).

43. Toleration policy regarding soft drugs and coffee shops. Government of the Netherlands. Available: www.government.nl/topics/ drugs/contents/toleration-policy-regarding-soft-drugs-and-coffee -shops (accessed 2015 June 4).

44. Police discover more marijuana plantations in Randstad region. DutchNews.nl 2015 Jan. 15. Available: www.dutchnews.nl/news/ archives/2014/01/police_discover_more_marijuana/ (accessed 2015 May 29).

45. Murkin G. Cannabis social clubs in Spain: legalisation without commercialization. Transform 2015 Jan. 6. Available: www.tdpf .org.uk/blog/cannabis-social-clubs-spain-legalisation-without -commercialisation\#.VLeZjsGV5R8.twitter (accessed 2015 May 16).

46. Resolución Slt/32/2015, De 15 de enero, por la que se aprueban criterios en materia de salud pública para orientar a las asociaciones cannábicas y sus clubes sociales y las condiciones de ejercicio de su actividad para los ayuntamientos de Cataluña. Diari Oficial de la Generalitat de Catalunya (Official Gazette of the Autonomous Government of Catalonia]. 2015 Jan. 29. Available: http://portaldogc.gencat.cat/utilsEADOP/PDF/6799/1402549.pdf (accessed 2015 Aug. 31)

47. Taylor H. Legislation passed to formally license Catalonia's cannabis clubs for first time. TalkingDrugs 2015 Feb. 3. Available: www.talkingdrugs.org/catalonia-cannabis-clubs-gain-formal -licensing (accessed 2015 May 16)

48. Measure 91: Control, regulation, and taxation of marijuana and industrial hemp act. People of the State of Oregon; 2014. Available: www.oregon.gov/olcc/marijuana/Documents/Measure91. pdf (accessed 2015 May 22).

49. Colorado Amendment 64: Use and regulation of marijuana. People of the State of Colorado; 2011. Available: www.fcgov. com/mmj/pdf/amendment64.pdf (accessed 2015 May 11).
50. Marijuana Enforcement Division 1 CCR 212-2: Permanent rules related to the Colorado Retail Marijuana Code. Denver: Colorado Department of Revenue: Marijuana Enforcement Division; 2013:109. Available: www.colorado.gov/pacific/sites/default/files/ Retail\%20Marijuana\%20Rules, \%20Adopted \%20090913,\%20 Effective\%20101513\%5B1\%5D 0.pdf (accessed 2015 May 12).

51. Initiative measure no. 502. People of the State of Washington; 2011. Available: http://sos.wa.gov/_assets/elections/initiatives/ i502.pdf (accessed 2015 May 23).

52. Caulkins JP, Kilmer B, MacCoun RJ, et al. Design considerations for legalizing cannabis: lessons inspired by analysis of California's Proposition 19. Addiction 2012;107:865-71.

53. Liquor Control Board clarifies next steps in its preparation to issue marijuana licenses [press release]. Olympia (WA): Washington State Liquor and Cannabis Board; 2014 Feb. 19. Available: www.liq.wa.gov/content/liquor-control-board-clarifies-next-steps -its-preparation-issue-marijuana-licenses (accessed 2015 May 11).

54. Frequently asked questions about I-502 advertising. Olympia (WA): Washington State Liquor and Cannabis Board; 2015. Available: http://liq.wa.gov/marijuana/faq_i502_advertising \#advertisingrules (accessed 2015 May 11).

55. Trans-High Corporation, D.B.A. High Times Magazine, The Daily Doobie, LLC a corporate entity; and The Hemp Connoisseur, LLC a corporate entity v. The state of Colorado and John Hickenlooper [civil action suit] 2013 May 29. Available: http://kln-law. com/images/news_images/Marijuana-Magazines-Complaint.pdf (accessed 2015 June 17).

56. Kilmer B. 7 key questions on marijuana legalization [blog]. Santa Monica (CA): Rand; 2013. Available: www.rand.org/blog /2013/04/7-key-questions-on-marijuana-legalization.html (accessed 2015 June 17).

57. Bula F. Vancouver to become first city to regulate medical pot dispensaries. The Globe and Mail [Toronto] 2015 Apr. 22. Available: www.theglobeandmail.com/news/british-columbia/vancouver-to -become-first-city-to-regulate-medical-pot-dispensaries/article 24071461/\%3b/ (accessed 2015 June 29).

58. Bailey I. Victoria mulling new bylaws for marijuana dispensaries. The Globe and Mail [Toronto] 2015 May 7. Available: www. theglobeandmail.com/news/british-columbia/victoria-mulling-new -bylaws-for-marijuana-dispensaries/article24324753/ (accessed 2015 June 23).

59. Campbell CS, Smith GJ. Gambling in Canada - from vice to disease to responsibility: a negotiated history. Can Bull Med Hist 2003;20:121-49.

60. Lower the stakes: a public health approach to gambling in British Columbia: Provincial health officer's 2009 annual report. Victoria: Office of the Provincial Health Officer BC; 2013. Available: www2.gov.bc.ca/gov/DownloadAsset?assetId=EB445906BC21437 EB4A44C1A075E3733\&filename=gambling-in-bc.pdf (accessed 2015 June 21.

61. Majority supports study to evaluate taxation and regulation of marijuana. Vancouver: Stop the Violence BC; 2013. Available: http://stoptheviolencebc.org/2013/04/18/majority-of -british-columbians-support-pilot-study-to-evaluate-taxation-and -regulation-of-marijuana (accessed 2015 Aug. 13)

62. Majority supports safe-injection sites. The Gazette [Montréal] 2008 June 7. Available: www.canada.com/montrealgazette/ story.html?id=f585e4fe-c262-41a8-b79a-d8329c379f26 (accessed 2015 June 5)

Affiliations: Department of Familiy Medicine (S. Spithoff), Women's College Hospital, Toronto, Ont.; Division of Population and Public Health (Emerson), BC Ministry of Health, Victoria, BC; Not For Sale — the Netherlands (A. Spithoff), Amsterdam, the Netherlands.

Contributors: Sheryl Spithoff conceived of and designed the article and wrote the first draft. Andrea Spithoff did most of the acquisition of data and critically revised the article. Brian Emerson contributed substantially to the analysis and interpretation of data and critically revised the article. All of the authors approved the final version to be published and agreed to act as guarantors of the work.

Acknowledgments: The authors thank Raquel Peyraube, Rebecca Jesseman, Meldon Kahan and the Women's College Academic Family Health Team Peer Support Writing Group for reviewing and providing helpful suggestions on earlier drafts of this paper. The authors also thank Pim Imenkamp, Laura Gutierrez and Rebecca Abavi for assisting in the background research for this paper.

Disclaimer: The opinions stated in this commentary are those of the authors and not of their affiliated organizations. 